\title{
HISTOPATHOLOGY AND HISTOCHEMISTRY OF YERSIN TYPE TUBERCULOSIS IN RABBITS \\ Histochemical Study of Development of the Disease after Infection with Mycobacterium avium
}

\author{
L. CERNÝ \\ Department of Pathological Morphology and Parasitology, University of Veterinary Science, \\ 61242 Brno
}

Received February 9, 1979

\begin{abstract}
Černý L.: Histopathology and Histochemistry of Yersin Type Tuberculosis in Rabbits. Histochemical Study of Development of the Disease after Infection with Mycobacterium avium. Acta vet. Brno, 48, 1979: 53-60.

Organs of rabbits infected intravenously Mycobacterium avium were studied to reveal dynamics of changes in content of nucleic acids, carbohydrates and lipid substances and formation of fibres during development of Yersin type tuberculosis.

Macrophages, young epitheloid cells and giant cells contained ribonucleic acid in their cytoplasm and nucleoli indicative of high activity of these cells. Gradually, amount of RNA in these cells diminished, first from their cytoplasm and then from the nucleoli and in prenecrotic stage the cells did not contain RNA at all.

Along with the development of tuberculous process, in the cells of epitheloid and giant type content of PAS-positive carbohydrates increased. Greater part of these were glycogen while caseous material contained complexes of carbohydrates and proteins.

In the cytoplasm of epitheloid and giant cells in the center of tuberculous foci, in necrotizing cells and in caseous material neutral fats, phospholipids, in later stages cholesterol and fatty acids were present. This finding showed that there was a metabolic disturbance of hypoxemic type.

Formation of reticulin fibres in tuberculous lesions was connected with presence of acid mucopolysaccharides.
\end{abstract}

Tuberculosis, Mycobacterium avium, Yersin type, histochemistry, nucleic acids, glycosaminoglycans, lipids, fibres.

Basic work in histochemistry of nucleic acids was performed by Brachet (1950) and Casperson (1950). It was stated that embryonic and growing tissues contained high amount of ribonucleic acid (RNA). Thus finding of increased amount of RNA is one of the characteristics of cellular activity. Content of RNA in the course of tuberculous infection was studied by Fridenštejn (1950), Averbach (1956), Henrichsen (1956), Hori et al. (1953a, b, 1957), Černý (1965) etc. These authors concluded that macrophages and young epitheloid cells contained high amount of RNA distributed in cytoplasm and nucleoli.

Studies of appearance of various lipid substances in course of tuberculosis have shown constant results. As soon as at the beginning of this century the finding of neutral fats in caseous necrosis was described (Herxheimer - 1902, Dietrich - 1909). Later the presence of neutral fats in tuberculous process was studied by Hori et al. (1953a, b), Černý (1965) and the same authors have described in caseous necrosis the presence of fatty acids and cholesterol. These findings were confirmed by Kondo and Kanai (1976).

PAS-positive sugars in course of tuberculous infection were seen in cytoplasm of epitheloid and giant cells and in caseous material as well (Hori et al. $1953 \mathrm{a}, \mathrm{b}$; Henrichsen 1957; Sorokin 1966; Williams et al. 1969; Nair 1973; Gudewicz and Filkins 1974, 1976 etc.). Acid mucopolysaccharides were also present especially in later stages of the process and their presence was connected with formation of reticular fibres.

The aim of this work was to evaluate findings of these substances and to study the dynamics in tuberculosis of rabbits due to Mycobacterium avium. 


\section{Materials and Methods}

In the experiment 15 rabbits infected intravenously Mycobacterium avium were used. Infective doses and the intervals of sacrifice of experimental animals were given in previous paper.

Tissue samples were fixed in neutral formol, Baker's fluid, Zenker's fluid and Carnoy's fluid and they were sectioned either using paraffin embedding or freezing microtom. The following staining methods were employed: Brachet method for RNA, gallocyanine method for both types of nucleic acids and Feulgen method for DNA, further the methods for glycosaminoglycans PAS, toluidine blue metachromatic stain, Halle method with coloid iron, alcian blue and Best method. The fibre formations were stained by van Gieson method, and Weigert method for elastic fibres and Gomori for reticulin fibres were used. Lipid substances were stained by Oil Red O, fatty acids using Fischler's method and cholesterol by Schultze's method while phospholipids were stained by Luxol blue.

\section{Results}

In organs of rabbits sacrificed up to 24 hours after infection no changes in content of studied substance weres present. However, 48 hours after infection proliferating cells, mainly alveolar macrophages, Kupffer's cells and spleen macrophages contained clear nucleoli with high content of RNA. Cytoplasm of few alveolar macrophages contained small amount of PAS-positive substances.

Five days after infection proliferating cells contained high amount of RNA in their cytoplasm and nucleoli, particularly prominent in Kupffer's cells and macrophages of the liver tissue. Similar picture was present also in the spleen and, to a lower degree, in the lungs. Free alveolar macrophages contained in their cytoplasm PAS-positive substances, partially glycogen. The fibre formation of liver

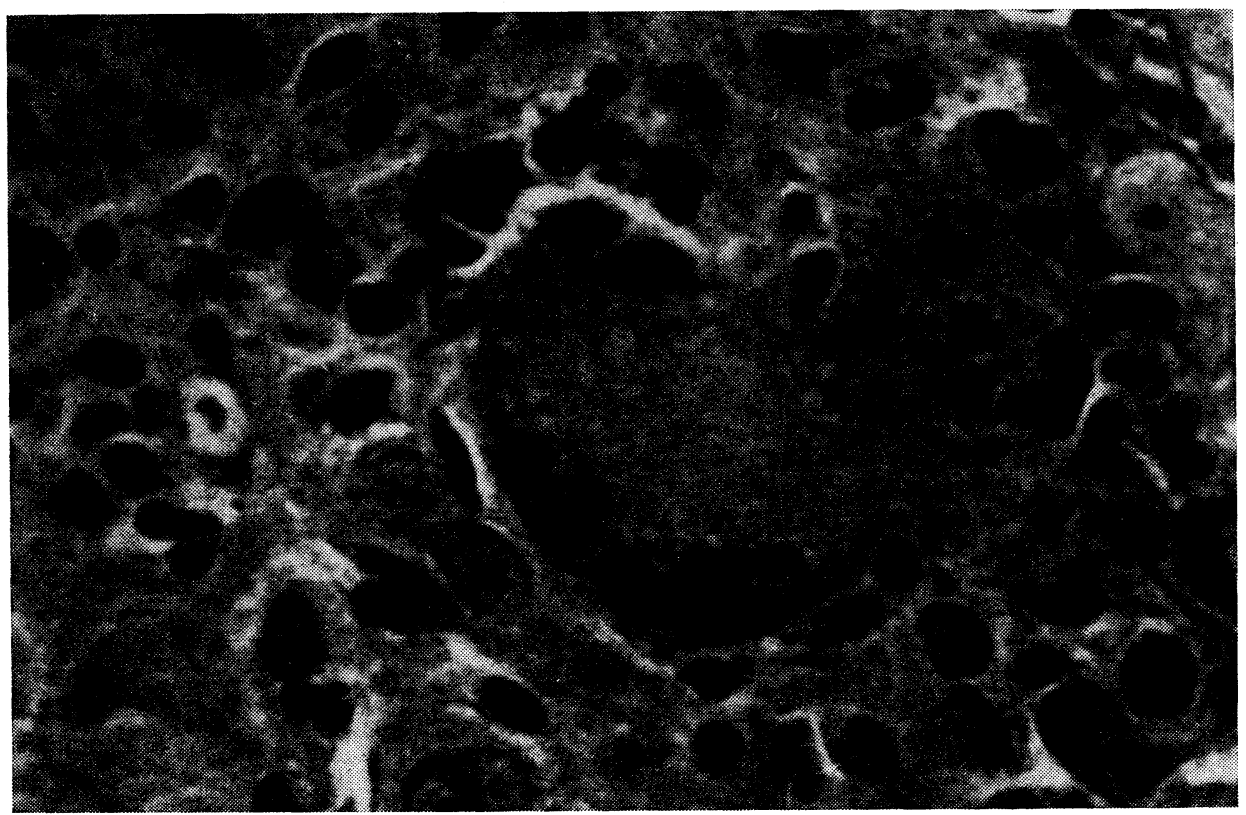

Fig. 1.

Multinucleated giant cell and epitheloid cells contain in their cytoplasm PAS-positive material - 14 days after infection. PAS-hematoxylin, $1600 \times$. 


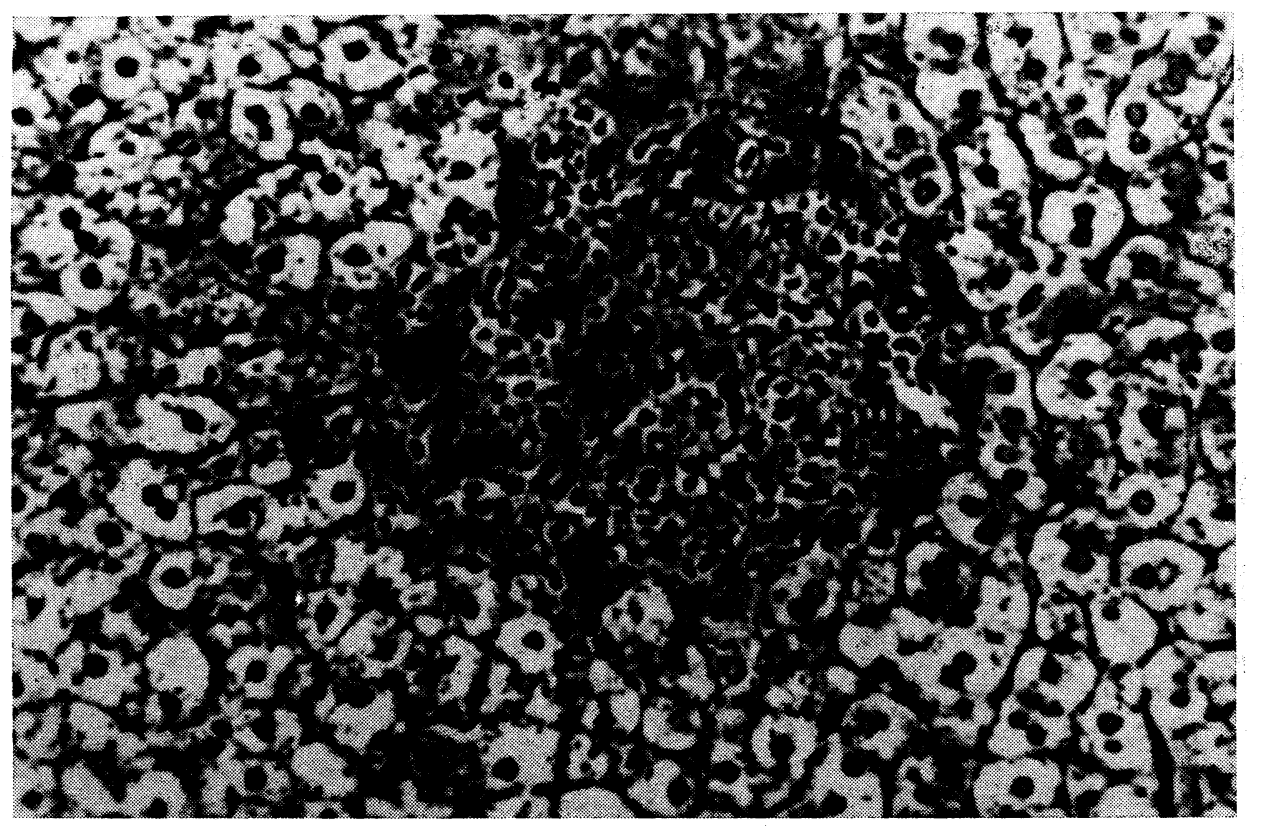

Fig. 2.

In the site of tuberculous nodule formation, original reticular structure of the liver disappeared. 14 days after infection. Gomori $-400 \times$.

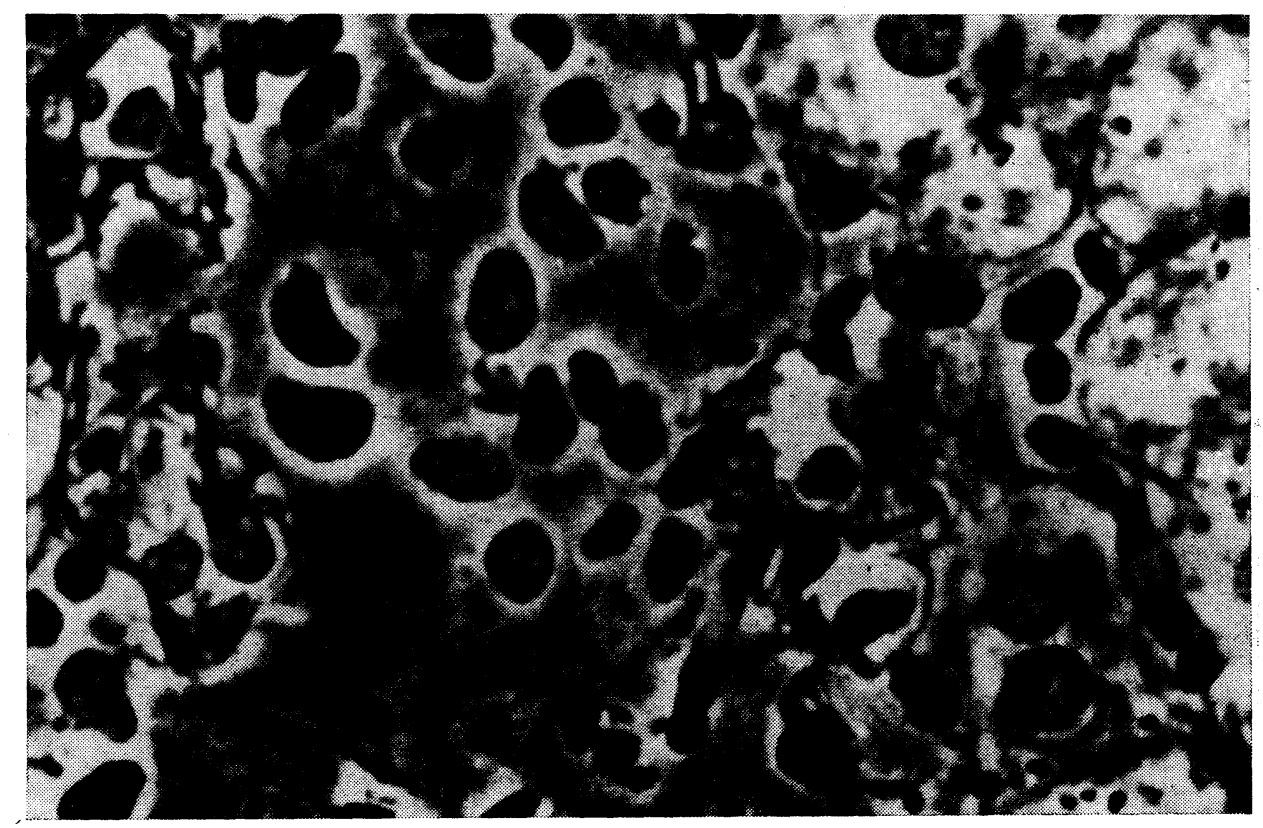

Fig. 3.

In tuberculous nodule new reticular fibres are formed. 16 days after infection. Gomori $-1600 \times$. 


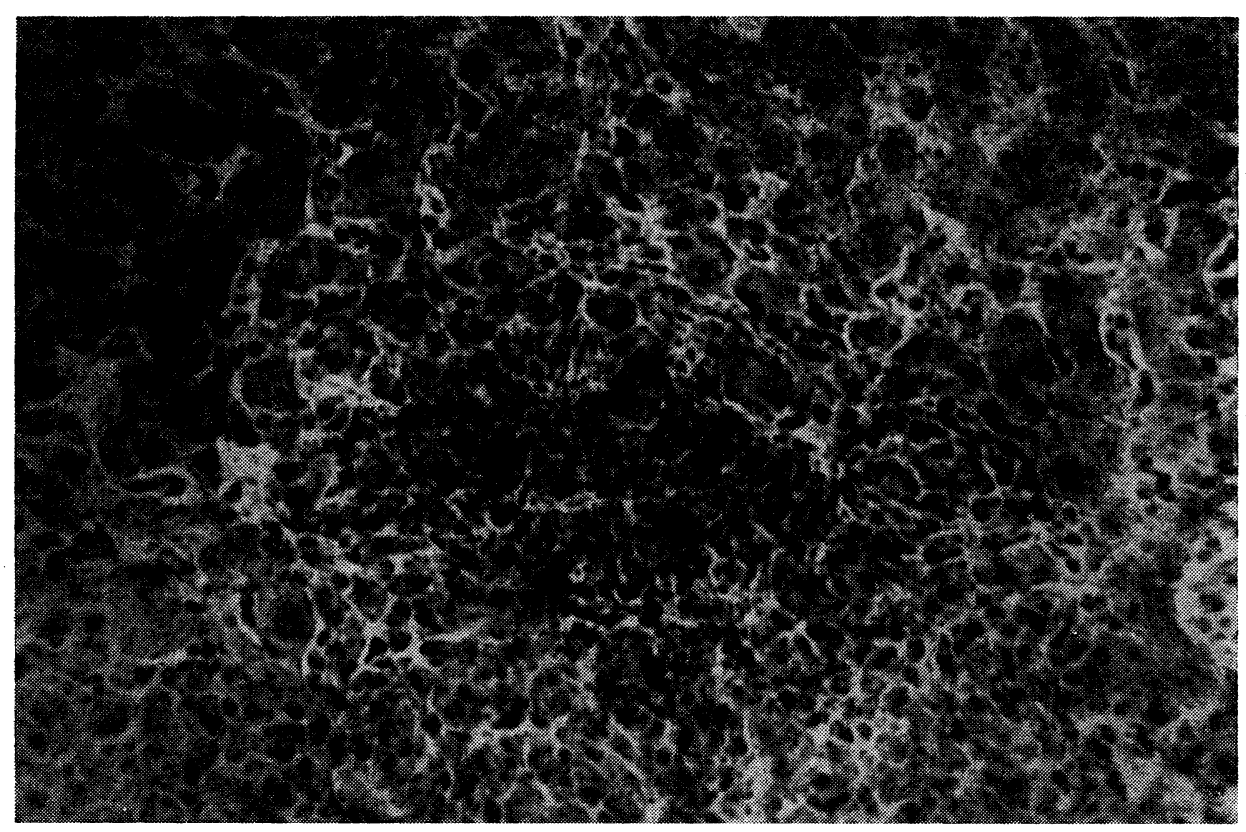

Fig. 4.

During necrobiotic changes content of neutral fats in the middle of focus increased. Oil Red $0-400 \times$.

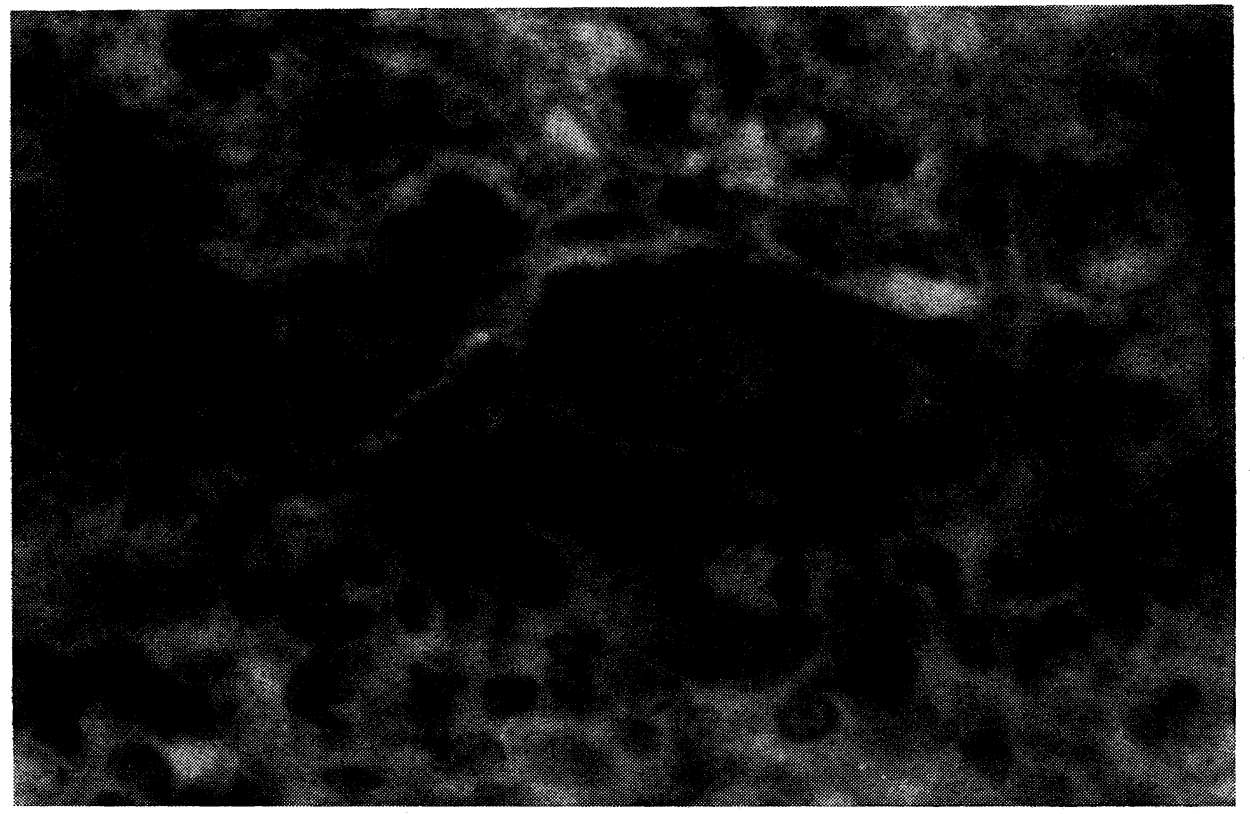

Fig. 5.

Giant cell and epitheloid cells revealed in cytoplasm presence of phospholipids. 14 days. Luxol blue $-1600 \times$. 
and lung was not changed and besides its PAS-positivity it stained also with alcian blue and metachromatically by toluidine blue - it contained acid mucopolysaccharides. In forming tuberculous lesions no lipid substances were present.

Seven days after infection most of the macrophages and forming epitheloid cells contained big nucleoli with RNA and high amount of this material in their cytoplasm. Exception from this rule was found in the lungs where alveolar macrophages contained limited amount of RNA but they revealed presence of PAS-positive substances and in few instances small droplets of neutral fat. Intercellular substance of some granulomas revealed presence of small amount of acid mucopolysaccharides.

Content of RNA especially in lungs changed in rabbits sacrificed 9 and 10 days after infection. Content of RNA in cytoplasm and nucleoli of most alveolar macrophages decreased while macrophages and young epitheloid cells in liver and spleen contained large amount of this substance. In sections stained by Feulgen method for DNA some nucleoli of alveolar macrophages revealed pycnotic changes with intensive staining. In cytoplasm of these cells increased amount of PAS-positive substances and neutral fats was observed.

Twelve and 14 days after infection the main feature of cells of tuberculous lesions was a lower amount of RNA. This picture was clear mainly in the cells localized in the centers of tuberculous foci. At the same time amount of PAS-positive substances in these cells increased. Alveolar macrophages underwent necrotic changes and this process was connected with loss of DNA. Findings of neutral fats and phospholipids were more prominent and in tuberculous lesions acid mucopolysaccharides were seen with formation of new reticulin fibres. Original reticular structure in these places was destroyed.

In lesions of both rabbits which died 16 and 18 days after infection content of RNA further decreased and in necrotic foci neither RNA nor DNA was present. Content of glycogen in the cytoplasm of epitheloid and giant multinucleated cells grew further and PAS-positive material was seen in the necrotic material as well. Intercellular substance revealed presence of acid mucopolysaccharides. Content of neutral fats, phospholipids, fatty acids and cholesterol increased in the cytoplasm of epitheloid and giant cells and in the necrotic material.

\section{Discussion}

Findings described in previous paper have shown development of tuberculous lesions in the rabbits infected intravenously with Mycobacterium avium. Some histochemical studies lead to the conclusion that young and active cells have high content of RNA in their cytoplasm and nucleoli (Kedrovskij - $1951 \mathrm{~b}$, Averbach 1956, Černý - 1965). In tuberculous lesions high content of RNA was seen mainly in macrophages, young epitheloid and giant cells, localized mostly in superficial layer of the nodule. Towards the center of nodules content of RNA decreases. This finding corresponded with previous work where epitheloid cells in the middle of nodules lost their ability to destroy mycobacteria and in these cells mycobacteria increased in number. According to these findings the content of RNA in cytoplasm and nucleoli of the cells of mononuclear macrophages system could be used as an indicator of phagocytic and destructive activity of these cells towards mycobacteria.

Necrotic foci of granulation tissue showed no presence of RNA and the changes applied to DNA as well. Pycnotic nuclei were stained intensively but in necrotic 
areas DNA disappeared. This finding was in accordance with study of Henrichsen (1956) and Dixon (1956). It was then possible to state that in the series monocyte (Kupffer's cell) - macrophage - epitheloid cell - giant cell, the highest content of RNA was in macrophage and young epitheloid cell, the older epitheloid and giant cells losing RNA from their cytoplasm first and then from their nucleoli.

Situation was completely different in findings of lipid substances in the cells of tuberculous tissue. Neutral fats and phospholipids appeared in cytoplasm of cells at the time when RNA disappeared and content of these substances increased towards necrosis. In necrotic material these substances were diffusely dispersed. Fatty acids and cholesterol appeared in necrotic area. Similar findings described Hori et al. (1S53a, b), Černý (1965), Kondo and Kanai (1976). It was evident that caseous necrosis developed through steatosis of cells. This process had hypoxemic character and was apparently connected with destruction of mitochondria and enzymatic disorder which leads to general disturbance of cellular metabolism.

Nearly in all stages of development of tuberculous lesions PAS-positive substances were present. Exception from this rule were macrophages and young epitheloid and giant cells; in their cytoplasm neither neutral fats nor phospholipids were present. Connected with ageing of these cells PAS-positive substances appeared and their amount intensively increased. These substances were mostly glycogen but PAS-positive material in necrotic areas gave no positive reaction for glycogen and this material was presumably formed by complexes of sugars and proteins. This finding was in accordance with studies of Nishyiama (1953), Henrichsen (1957), Hori et al. (1957), Nair (1973). Presence of glycogen in cells of various granulomas confirmed also Lowell et al. (1966), Curran et al. (1966), Gudewicz and Filkins (1974, 1976). These substances infiltrated apparently the cells in the process of diminishing their metabolic activity. The process was seen in the period of decreased content of RNA and increased number of mycobacteria that is in period of decreased metabolic activity of cells of tuberculous tissue.

Acid mucopolysaccharides appeared in tuberculous lesions in later stages of development of the process (12-14 days) and their presence was apparently connected with the reticulin fibres formation, indicating that the process of fibre formation in tuberculous lesions was similar to that in non-specific tissue and was connected with basic intercellular substance.

It was shown that described histochemical examination of tuberculous granulomas could be used to state the activity of cells of macrophages system in phagocytosis of tuberculous mycobacteria.

\section{Histopatologie a histochemie Yersinova typu tuberkulózy u králíků. Histochemické studium vývoje onemocnění po infekci Mycobacterium avium}

$\mathrm{Na}$ orgánech králiků, infikovaných intravenózně Mycobacterium avium, byla sledována dynamika změn obsahu nukleových kyselin, cukrů a tukových látek a vývoj vláknitých útvarů během rozvoje Yersinova typu tuberkulózy.

Makrofágy, mladé epiteloidní buňky i mladé obrovské buňky obsahují v cytoplasmě i v jadérku RNK, což svědčí o vysoké aktivitě těchto buněk. Postupně se $\mathrm{z}$ buněk granulační tkáně RNK ztrácí, nejdříve z cytoplasmy, pak z jadérka a $\mathrm{v}$ období před nekrotizací buněk se již nenachází. 
$S$ rozvojem procesu se zvyšuje $\mathrm{v}$ buňkách typu epiteloidních a obrovských buněk množství PAS-pozitivních cukrů, $\mathrm{z}$ nichž větší část tvoři glykogén. Kaseózni hmota obsahuje komplexy cukrů a bílkovin.

V cytoplasmě epiteloidních a obrovských buněk v centru ložisek, v nekrotizujících buňkách a v nekrotické hmotě se nacházejí neutrální tuky a fosfolipidy, $v$ pozdějších stadiích $i$ cholesterol a mastné kyseliny. Je to svědectví o narušení metabolismu buněk hypoxemického typu.

Tvorba retikủárních vláken $\mathrm{v}$ tuberkulózní granulační tkáni je spojena s nálezy kyselých mukopolysacharidů.

Гистология и гистохимия типа Иерсена туберкулеза кроликов.

Гистохимические исследования развития заболевания после инфекции M. avium

На органах инфицированных внутривенозно Mycobacterium avium кроликов проводились исследования динамики изменений содержания нуклеиновых кислот, сахаров и жировых веществ и развитие волокнистых образований в течение развития туберкулеза типа Иерсена.

Макрофаги, небольшие эпителиоидные клетки и молодые гигантские клетки содержат в цитоплазме и ядрышке РНК, что свидетельствует о высокой активности данных клеток. РНК постепенно из клеток грануляционной ткани исчезает, сперва из цитоплазмы, потом из ядрышка и в период перед некротизацией клеток его уже нет.

С развитием процесса в клетках эпителиоидного и гигантского типов увеличивается количество ПАСК - позитивных сахаров, большую часть из них образует гликоген. Казеозная масса содержит комплексы сахаров и белков.

В цитоплазме эпителиоидных и крупных клеток в центре очагов, в некротизирующих клетках и в некротической массе находятся нейтральные жиры и фосфалипиды, на более поздних стадиях также холестерин и жирные кислоты. Это свидетельствует о нарушении метаболизма клеток гипоксемического типа.

Образование ретикулярных волокон в туберкулезной грануляционной ткани связано с выявлением кислых мукополисахаридов.

\section{References}

AVERBACH, A. M.: K gistochimičeskoj charaktěristike morfologičeskich reakcij pri lečenii eksperimentalnogo tuberkuleza antibiotikami i chimiopreparatami. Probl. tuberk., 34, 1956: $43-52$.

BRACHET, J.: Lokalizacija i věrojatnaja rolj nukleinovych kislot $\mathrm{v}$ kletke i v embrioně. Usp. sovr. Biol., 29, 1950: 140-144.

CASPERSON, T.: Cell growth and cell function., New York, 1950.

CURRAN, R. C. - LOWELL, D. - CLARK, A. E.: Mucopolysaccharides in peritoneal granulomas in the rat. J. Path. Bact., 91, 1966: 429-440.

ČERNÝ, L.: Př́spěvek $\mathrm{k}$ patogeneze tuberkulózy a některé histochemické studie tuberkulózní granulační tkáně. Thesis, Brno, 1965, 177pp.

DIETRICH, A.: Die Störungen des Zellulären Stoffwechsels. Erg. allg. Path., 13/II, 1909: $282-355$.

DIXON, K. C.: Protein and nucleic acids in caseous necrosis. Amer. Rev. Tb. pulm. Dis., 77, 1958: $106-119$.

FRIDENSTEJN, A. Ja.: O razpredelenii nukleinovych kislot $\mathrm{v}$ specifičeskich granulomach pri eksperimentalnoj tuberkuleznoj infekcii i vakcinnom processe. Bjul. exp. Med. i Biol.; 41, 1950: $67-77$.

GUDEWICZ, P. W. - FILKINS, J .P.: Glycogen metabolism in macrophages: Effect of exogenous glycogen, glucogenesis in inflammatory exudate, leucocytes and macrophages. RESJ. Reticuloendothel. Soc., 16, 1974: 1-8. 
GUDEWICZ, P. W. - FILKINS, J. P.: Glycogen metabolism in inflammatory macrophages. RES-J. Reticuloendothel. Soc., 20, 1976: 147-157.

HENRICHSEN, E.: Alkaline phosphatase and calcification in tuberculous lymph nodes. Exp. Cell. Res., 11, 1956: 511-519.

HERXHEIMER, G.: Über Fett-infiltration und Degeneration. Erg. allg. Path., 8, 1902: 624-658.

HORI, M. - HATTORI, S. - HAGIHARA, T.: Histochemical study on the histogenesis of tuberculous lesions in the lung. I. Nucleic acids, alkaline phosphatase, acid mucopolysaccharides in pulmonary lesions of tuberculous patients. Med. J. Osaka Univ., 4, 1953: 329-340.

HORI, M. - HATTORI, S. - HAHIGARA, T.: Histochemical study on the histogenesis of tuberculous lesions in the lung. II. Histogenesis of pulmonary tuberculosis in guinea pigs. Med. J. Osaka Univ., 4, 1953: 341-351.

HORI, M. - HATTORI, S. - HIRAYASU, R. - SUZUKI, K.: Histochemical studies on calcification of tuberculous lesions. Med. J. Osaka Univ., 7, 1957: 777-785.

LOWELL, D. - SCHORAH, C. J. - CURRAN, R. C.: Glycosaminoglycans in experimental granulomata. Brit. J. exp. Pathol., 47, 1966: 228-234.

NAIR, M. K.: The early inflammatory reaction in the fowl. A light microscopical, ultrastructural and autoradiographic study. Acta vet. Scand., Suppl. 42, 1973: 103pp.

SOROKIN, S. P.: A morphologic and cytochemical study of the great alveolar cell. J. Histochem. Cytochem., 14, 1966: 884-897.

WILLIAMS, D. - WILLIAMS, W. J. - WILLIAMS, J. E.: Enzyme histochemistry of ep itheloid cells in sarcoidosois and sarcoid-like granulomas. J. Pathol. (Edinburgh), 97, 1969: 705-709.

KONDO, Eixo. - KANAI, Koomi.: Accumulation of cholesterol esters in macrophages incubated with Mycobacteria in vitro. Jap. J. med. Sci. Biol., 29, 1976: 123-137. 